\title{
Life Cycle Energy of Low Rise Residential Buildings in Indian Context
}

\author{
Talakonukula Ramesh ${ }^{1}$, Ravi Prakash ${ }^{2}$, Karunesh Kumar Shukla ${ }^{3}$ \\ ${ }^{1}$ Government Polytechnic, Nirmal, India \\ ${ }^{2}$ Department of Mechanical Engineering, Motilal Nehru National Institute of Technology, Allahabad, India \\ ${ }^{3}$ Department of Applied Mechanics, Motilal Nehru National Institute of Technology, Allahabad, India \\ Email: rams2dg@gmail.com
}

Received 6 October 2014; revised 6 November 2014; accepted 23 November 2014

Copyright (C) 2014 by authors and Scientific Research Publishing Inc.

This work is licensed under the Creative Commons Attribution International License (CC BY).

http://creativecommons.org/licenses/by/4.0/

c) (i) Open Access

\begin{abstract}
Life cycle energy of the building accounts for all energy inputs to the buildings during their intended service life. Buildings need to be constructed in such a way that energy consumption in their life cycle is minimal. Life Cycle Energy (LCE) consumption data of buildings is not available in public domain which is essentially required for building designers and policy makers to formulate strategies for reduction in LCE of buildings. The paper presents LCE of twenty (20) low rise residential buildings in Indian context. LCE of the studied buildings is varying from $160-380 \mathrm{kWh} / \mathrm{m}^{2}$ year (Primary). Based on the LCE data of studied buildings, an equation is proposed to readily reckon LCE of a new building.
\end{abstract}

Keywords

Life Cycle Energy, Residential Buildings, Embodied Energy, Operating Energy

\section{Introduction}

Building construction sector is experiencing a fast-paced growth in developing countries, like India, due to growth of economy and rapid urbanization. A large number of buildings are being built for residential, commercial and office purposes every year. In India, 24\% of primary energy and 30\% of electrical energy is consumed in buildings [1]. The use of electricity in this sector is growing at the rate of $11 \%-12 \%$ annually, which is $100 \%$ more than the average growth rate of $5 \%-6 \%$ in the economy [2]. Besides the depletion of non-renewable energy sources, this energy use contributes greenhouse gases to the atmosphere, with consequent detrimental effects. In order to reduce the detrimental environment impacts of the buildings, new buildings need to be planned in such a way that energy consumption in their life cycle is minimal. In spite of the fast-paced growth of

"Corresponding author. 
the building sector in India, Life Cycle Energy (LCE) consumption data for this sector is not available in the public domain; whereas a lot of work has been done in cold and western countries. Absence of macro-level data has been a barrier for the government to formulate effective policies to make the buildings energy-efficient.

Life cycle energy of the building accounts for all energy inputs to the buildings during their intended service life. It includes direct energy inputs during construction, operation and demolition phases of the buildings, and indirect energy inputs through the production of components and materials used in construction (embodied energy). If LCE is expressed in primary energy terms, it also gives a useful indication of environmental impacts attributable to buildings as primary energy consumption and associated emissions are proportional [3]-[5]. Life cycle energy evaluation of buildings becomes necessary not only for evaluating energy performance of the existing buildings but also to set a meaningful target for construction industry to construct new buildings with reduced energy demand, i.e. low energy buildings.

\section{Low Energy Buildings}

It is reported in different case studies available in the literature that operating energy of the buildings has largest share $(80 \%-90 \%)$ and embodied energy constitutes $10 \%-20 \%$ in its life cycle energy distribution. Thus, the most important aspect for the design of buildings which demand less energy throughout their life cycle (low energy buildings) is the reduction in operating energy [6]-[8]. In order to reduce operational energy demand of the buildings, passive and active measures such as providing higher insulation on external walls and roof, using gas filled multiple pane windows with low emissivity coatings, ventilation air heat recovery from exhaust air, heat pumps coupled with air or ground/water heat sources, solar thermal collectors and building integrated solar photovoltaic modules, etc. can be used. But, reduction in operating energy is generally accompanied by increase in embodied energy of the buildings due to energy intensive materials used in the energy saving measures and on-site power generating equipment integrated with building.

Though embodied energy constitutes only $10 \%$ - 20\% to life cycle energy, opportunity for its reduction should not be ignored. There is a potential for reducing embodied energy requirements through use of materials in the construction that requires less energy during manufacturing [9]. While using low energy materials, attention must be focused on their thermal properties and longevity as they have impact on energy use in operating phase of a building's life cycle. Thus, energy saving measures aimed at reducing one phase of energy use (operating) has impact on other phase of energy use (embodied energy) of the building. Hence, holistic evaluation of the buildings covering all phases of energy use is required to assess energy performance of the buildings. Another opportunity for reducing embodied energy is through use of recycled materials in the construction.

The present paper focuses on evaluation and presentation of LCE data of low rise residential buildings in Indian context. LCE of the buildings was evaluated for existing (conventional) and modified designs. Building designs are modified by applying energy saving measures viz. thermal insulation on wall and roof, double pane glass for windows and with on-site power generation equipment (PV modules). Such a study is expected to be useful for building designers and policy makers for holistic evaluation of buildings from life cycle perspective.

\section{Methodology}

A total of 20 house designs (Table 1) are obtained from house builders, consultants and owners of the buildings. All buildings are conventional houses with RCC frame work, walls filled with fired clay bricks, and RCC roof. The buildings are categorized by number of floors they have viz. one storey, two storey, and multi storey. Each floor contains one or more family portions consisting of bed rooms, drawing room, living room, and a kitchen. Bedrooms and living hall are air conditioned. The information of buildings such as usable floor area, conditioned area, number of families living, operating hours, etc have been collected.

Electricity from the national grid is being used for all operations of the buildings like running air conditioners, domestic appliances, water heating and lighting etc. The indoor operating set point temperature is around $25^{\circ} \mathrm{C}$ for cooling, $18^{\circ} \mathrm{C}$ for heating and all lighting controls of the building are manual. Bed rooms and living hall are air conditioned using window air conditioners having COP of 3 for cooling and 0.9 for heating (electrical resistance heating) for design conditions. Though, electrical resistance heating is not advisable, it is common in India, as harsh winter in most parts of the country lasts only for one or two months and people do not use heat pump or boiler for heating. The air conditioner utilization is about 11 hours on an average for bedrooms and 4 hours for the living room starting in the evening hours for all working days. On holidays, air conditioners start working in the afternoon 13.00 hours onwards. Detailed estimation of energy required for the production (embodied energy- 
EBE) and operation phases of the buildings from a primary energy perspective is being considered. LCE of the buildings are evaluated for different locations (Allahabad, Ahmedabad, Hyderabad, Chennai and Bangalore) under different climatic zones of India viz: hot and dry, warm and humid, moderate, and composite (Figure 1).

Table 1. Details of the buildings studied.

\begin{tabular}{|c|c|c|c|c|c|c|}
\hline BIN & Name & Category & $\begin{array}{c}\text { Floor Area } \\
\left(\mathbf{m}^{2}\right)\end{array}$ & $\begin{array}{l}\text { Conditioned } \\
\text { area }\left(\mathbf{m}^{2}\right)\end{array}$ & Description & Location \\
\hline 1 & Resha & One storey & 80 & 36 & Single family, 3 BR house & Hyderabad \\
\hline 2 & Harish & One storey & 90 & 42 & Single family, 2 BR house & Hyderabad \\
\hline 3 & Janardhan & One storey & 102 & 55 & Single family, 2 BR house & Hyderabad \\
\hline 4 & Goud & One storey & 86 & 47 & Single family, 2 BR house & Hyderabad \\
\hline 5 & Eashwer & One storey & 185 & 104 & $\begin{array}{c}\text { Two families, 2BR portion-1, } \\
\text { 1BR portion-1 }\end{array}$ & Hyderabad \\
\hline 6 & Srinivas & One storey & 155 & 102 & Two families, single BR portions-2 & Hyderabad \\
\hline 7 & Ravindra & One storey & 107 & 71 & Single family, 2BR house & Hyderabad \\
\hline 8 & Adil & One storey & 62 & 46 & Two families, single BR portions-2 & Hyderabad \\
\hline 9 & Keerthi & One storey & 104 & 86 & Single family, 3BR house & Hyderabad \\
\hline 10 & Abhishek & Two storey & 256 & 136 & Two families, 3BR portions-2 & Hyderabad \\
\hline 11 & Alwal & Two storey & 135 & 80 & Two families, single BR portions-2 & Hyderabad \\
\hline 12 & Nirmal & Two storey & 235 & 155 & Two families, 3BR portions-2 & Hyderabad \\
\hline 13 & Mahipal & Two storey & 268 & 180 & Multy families, single BR flats-8 & Hyderabad \\
\hline 14 & Anand & Duplex & 183 & 100 & Single family, 4BR house & Hyderabad \\
\hline 15 & RG & Duplex & 175 & 120 & Single family, 4BR house & Hyderabad \\
\hline 16 & Mahendra & Duplex & 450 & 340 & Single family, 4BR house & Ahmedabad \\
\hline 17 & Kiran Arcade & Multi storey & 1286 & 600 & Multy families, single BR flats-15 & Hyderabad \\
\hline 18 & Renuka & Multi storey & 590 & 350 & Multy families, two BR flats- 12 & Hyderabad \\
\hline 19 & Pradeep & Multi storey & 854 & 430 & Multy families, single BR flats- 12 & Hyderabad \\
\hline 20 & Rock town & Multi storey & 1280 & 1024 & Multy families, 3BR flats-4, 2BR flats-8 & Hyderabad \\
\hline
\end{tabular}

BIN: Building Identification Number.

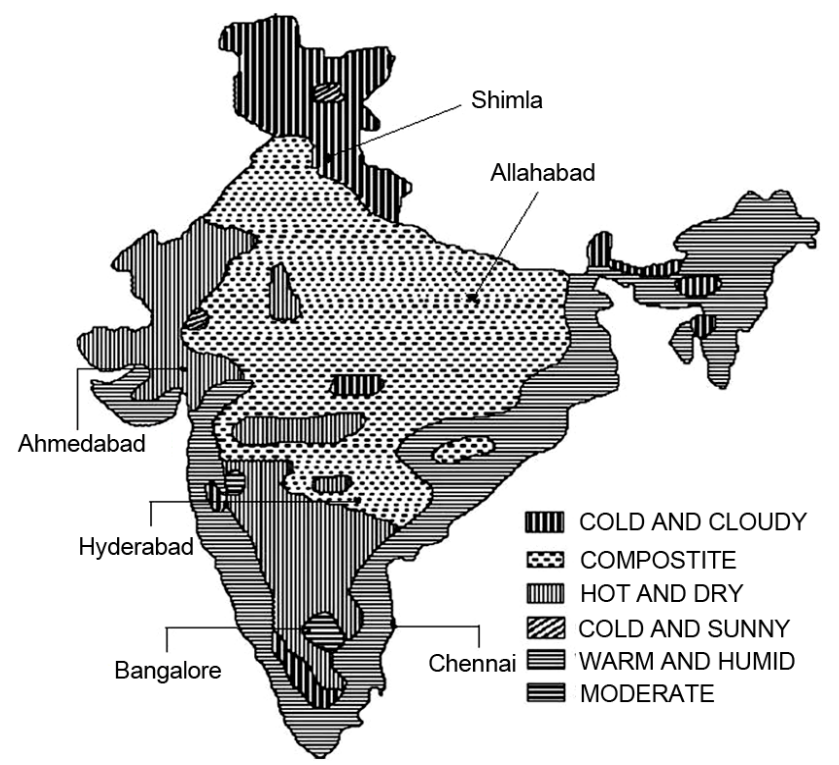

Figure 1. Map showing locations of the cities under different climatic zones of India. 


\section{Life Cycle Energy}

LCE demand of the building is taken as the sum of the embodied energy of materials used in the construction (EBE) and operating energy (OPE) on an assumed lifespan of 75 years using following relation [10] [11]:

$$
\mathrm{LCE}=\sum m_{i} M_{i}+E_{A} L_{b}
$$

where

$m_{i}=$ Quantity of building material (i),

$M_{i}=$ Embodied energy of material (i) per unit quantity (Table 2),

$E_{A}=$ Annual Operating Energy (primary), $L_{b}=$ Lifespan of the building (75 years).

Energy used for on-site construction and demolition at the end of its service life are ignored in the study as they contribute little (1\%) to LCE [10]-[14]. Unit for LCE is chosen as kWh (thermal). However, normalized LCE per unit floor area and per year is useful for quick comparison of energy performance of buildings of different sizes or different design versions of a building. Hence, LCE and other energy entities (OPE and EBE) of the building are normalized to $\mathrm{kWh} / \mathrm{m}^{2}$ year based on their floor area and assumed lifespan of 75 years. Quantity of materials is estimated from the technical drawings of the buildings using QE-Pro software [15]. Embodied energy per unit quantity of building materials are compiled from literature [16]-[19].

The energy used for the renovation of buildings is included in EBE of the building. Annual electricity demand of the building is estimated by energy simulation of the building using dynamic energy simulation tool design builder [20]. The evaluated energy (electricity) demand of the buildings is then converted into primary energy using a conversion factor of 3.4 [21] for the Indian context and is termed as annual operating energy $\left(E_{A}\right)$. Annual operating energy of the building is assumed to be same in future throughout its life span.

LCE demand is estimated for existing (conventional-Case A) and modified designs of the buildings for different climatic conditions of India. Building designs are modified by applying energy saving measures: adding 5 $\mathrm{cm}$ thick thermal insulation to wall and roof, and double pane glass for windows (Case B). LCE demand of the conventional building under particular climatic condition is taken as the base case for calculating energy savings. Further, LCE of the buildings is also evaluated with on-site power generating equipment (PV system). The embodied energy of PV modules, for initial installation and replacement, is included in calculation of EBE of the building. Number of times the PV modules are replaced is calculated using following relation:

$$
N=\left(L_{b} / L_{i}-1\right)
$$

where

$N=$ No of times the PV modules are replaced in life span of building,

$L_{b}=$ Lifespan of the building,

$L_{i}=$ Lifespan of PV modules (Table 3).

Table 2. Embodied energy of building materials.

\begin{tabular}{cccc}
\hline Name of the Material & Unit & Embodied Energy per Unit (GJ) & Reference Source \\
\hline Cement & ton & 6.7 & {$[16]$} \\
Steel & ton & 28.212 & {$[16]$} \\
Fired clay bricks & $\mathrm{m}^{3}$ & 2.235 & {$[16]$} \\
Aggregate & $\mathrm{m}^{3}$ & 0.538 & {$[16]$} \\
Glass & ton & 25.800 & {$[17]$} \\
Copper & ton & 110.000 & {$[16]$} \\
Ceramic tiles & ton & 3.333 & {$[16]$} \\
PVC & ton & 158.000 & {$[19]$} \\
Marble/Granite & ton & 1.080 & {$[19]$} \\
AC blocks & $\mathrm{m}^{3}$ & 0.818 & {$[19]$} \\
Fly ash bricks & $\mathrm{m}^{3}$ & 1.341 & {$[18]$} \\
Expanded polystyrene (EPS) & $\mathrm{m}^{3}$ & 2.500 & 236.8 \\
Aluminum & ton & & {$[16]$} \\
\hline
\end{tabular}


Table 3. Particulars of PV modules.

\begin{tabular}{cc}
\hline Parameter & Value \\
\hline Wattage per module & $75 \mathrm{~W}_{\mathrm{p}}$ \\
Short circuit current $I_{s c}$ & $4.8 \mathrm{~A}$ \\
Open circuit voltage $V_{o c}$ & $21 \mathrm{~V}$ \\
Maximum current $I_{\max }$ & $4.5 \mathrm{~A}$ \\
Maximum voltage $V_{\max }$ & $16.5 \mathrm{~V}$ \\
Area of single module & $0.6 \mathrm{~m}^{2}$ \\
Type of cell & Single crystalline silicon \\
Number of cells in a module & 36 \\
Life span & 30 years \\
Embodied energy of PV system (primary) & $1710 \mathrm{kWh} / \mathrm{m}^{2}$ \\
\hline
\end{tabular}

Electricity generated from PV modules is simulated using e-Quest software [22] for different climatic conditions of India. PV modules and storage devices (batteries) are designed as explained in the reference [23]. Specifications and other particulars of PV modules are shown in Table 3.

\section{Results and Discussion}

The results obtained from the life cycle energy analysis of the buildings under different conditions are presented herein. Table 4 presents the life cycle energy (LCE) demand of the conventional buildings studied under different geographical locations of India. LCE of the buildings is varying from about $160-380 \mathrm{kWh} / \mathrm{m}^{2}$ year. There is wide variation in LCE demand of the buildings. The reasons for this variation could be attributed to differences in climatic conditions, conditioned floor area and layout of the buildings. However, LCE range of buildings for composite, hot and dry, warm and humid climates is almost same and it is about $200-380 \mathrm{kWh} / \mathrm{m}^{2}$ year whereas for moderate climate it is $160-270 \mathrm{kWh} / \mathrm{m}^{2}$ year. Single storey houses require higher LCE than two and multi-storey house under similar operating and climatic conditions. This is due to the fact that, single storey houses require higher operating energy than two and multi-storey houses as they have higher external surface area per $\mathrm{m}^{2}$ of usable floor area which results in higher thermal load and energy consumption by cooling and heating equipment. Besides this, embodied energy of single storey houses is also higher than two and multistorey houses. With increase in number of floors, external surface area per usable floor area comes down and hence multi-storey houses show better energy performance among the three.

Figures 2-4 show the variation of annual operating (electrical) energy demand of the buildings with conditioned floor area for different locations. It is observed that annual operating energy demand of the building is increasing with increase in conditioned floor area. Regression analysis is performed to obtain a relation between annual operating energy (electrical energy) and conditioned floor area of the buildings. A second order polynomial equation $\left(R^{2}=0.98\right)$ can be best fit curve among the others-linear $\left(R^{2}=0.97\right)$ and exponential $\left(R^{2}=0.8\right)$. The relation between conditioned floor area and annual operating energy cannot be linear at higher conditioned floor areas. The reason is generally higher conditioned floor areas exist in multi-floor buildings; with increase in number of floors, external surface area per unit floor area of the building comes down thereby reducing the rate of increase in air conditioning load and corresponding operating energy of the building. Hence, the relation between conditioned floor area and annual operating energy becomes non linear with increase in conditioned floor area.

Hence, second order polynomial equation can be chosen to estimate annual operating primary energy $\left(E_{A}\right)$ of the buildings.

$$
E_{A}=3.4\left(A X^{2}+B X+C\right)
$$

where

$X=$ Conditioned floor area of the building $\left(\mathrm{m}^{2}\right)$,

$A, B$ and $C$ are regression coefficients and are shown in Table 5 . 
Further, it is observed that embodied energy of the buildings for single storey buildings is varying from 25 to $30 \mathrm{kWh} / \mathrm{m}^{2}$ year (average $27.5 \mathrm{kWh} / \mathrm{m}^{2}$ year) and for two and multi storey houses it is varying from 18 to 25 $\mathrm{kWh} / \mathrm{m}^{2}$ year (average $22 \mathrm{kWh} / \mathrm{m}^{2}$ year) As variation in embodied energy of the buildings is not high, the average of the above values are taken as standard to represent embodied energy of single, two and multy-storey houses respectively.

Table 4. LCE demand of the residential buildings for different locations.

\begin{tabular}{|c|c|c|c|c|c|c|c|}
\hline \multirow{2}{*}{ BIN } & \multirow{2}{*}{ Name } & \multirow{2}{*}{ Embodied energy $\mathrm{kWh} / \mathrm{m}^{2}$ year } & \multicolumn{5}{|c|}{ Life cycle energy $\mathrm{kWh} / \mathrm{m}^{2}$ year } \\
\hline & & & Hyderabad & Ahmedabad & Allahabad & Chennai & Bangalore \\
\hline 1 & Resha & 29.4 & 265 & 276 & 304 & 313 & 226 \\
\hline 2 & Harish & 27.6 & 232 & 269 & 270 & 274 & 198 \\
\hline 3 & Janardhan & 29 & 193 & 218 & 219 & 209 & 165 \\
\hline 4 & Goud & 28 & 203 & 242 & 243 & 235 & 164 \\
\hline 5 & Eashwer & 21 & 267 & 293 & 288 & 300 & 247 \\
\hline 6 & Srinivas & 25 & 259 & 298 & 297 & 301 & 223 \\
\hline 7 & Ravindra & 25.2 & 269 & 304 & 309 & 310 & 230 \\
\hline 8 & Adil & 27.4 & 294 & 330 & 346 & 335 & 249 \\
\hline 9 & Keerthi & 28 & 327 & 376 & 368 & 357 & 254 \\
\hline 10 & Abhishek & 24.2 & 246 & 280 & 280 & 288 & 201 \\
\hline 11 & Alwal & 18.5 & 266 & 297 & 291 & 290 & 197 \\
\hline 12 & Nirmal & 23.5 & 271 & 305 & 315 & 300 & 230 \\
\hline 13 & Mahipal & 18.3 & 278 & 318 & 325 & 322 & 225 \\
\hline 14 & Anand & 21.5 & 255 & 285 & 288 & 294 & 207 \\
\hline 15 & RG Reddy & 22 & 276 & 318 & 303 & 315 & 221 \\
\hline 16 & Mahendra & 25 & 301 & 334 & 332 & 345 & 256 \\
\hline 17 & Kiran Arcade & 22 & 247 & 272 & 276 & 280 & 210 \\
\hline 18 & Renuka & 25 & 298 & 336 & 334 & 347 & 243 \\
\hline 19 & Pradeep & 21 & 230 & 255 & 260 & 264 & 192 \\
\hline 20 & Rock town & 23 & 317 & 349 & 346 & 364 & 269 \\
\hline
\end{tabular}

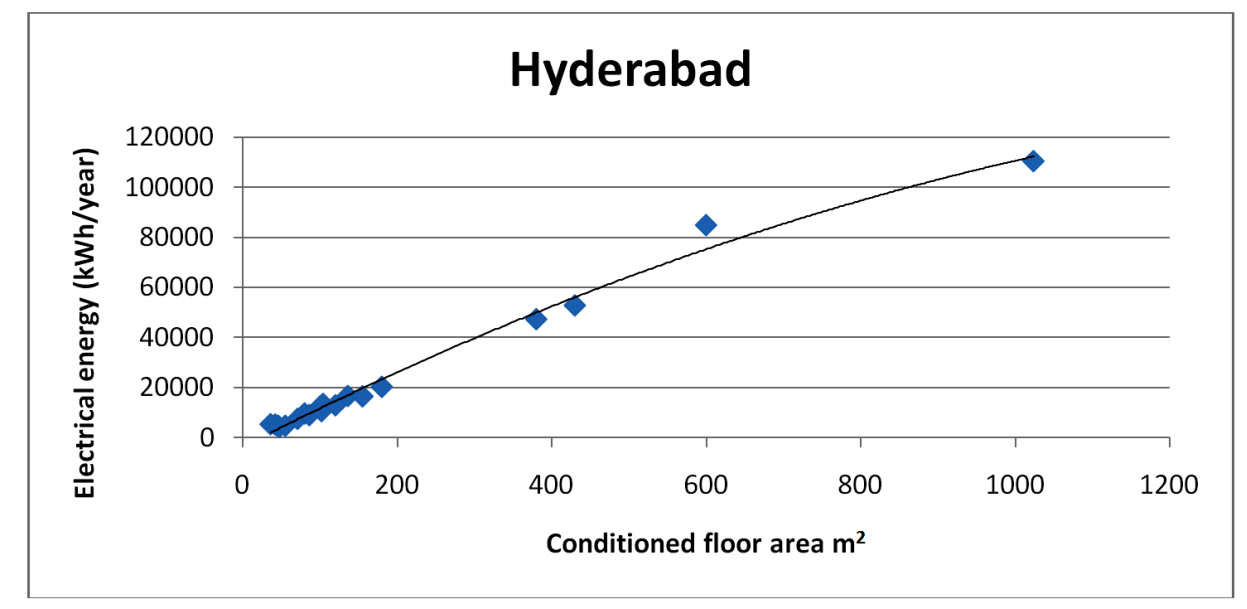

Figure 2. Variation of electrical energy demand of the buildings with conditioned floor area (Hyderabad location). 


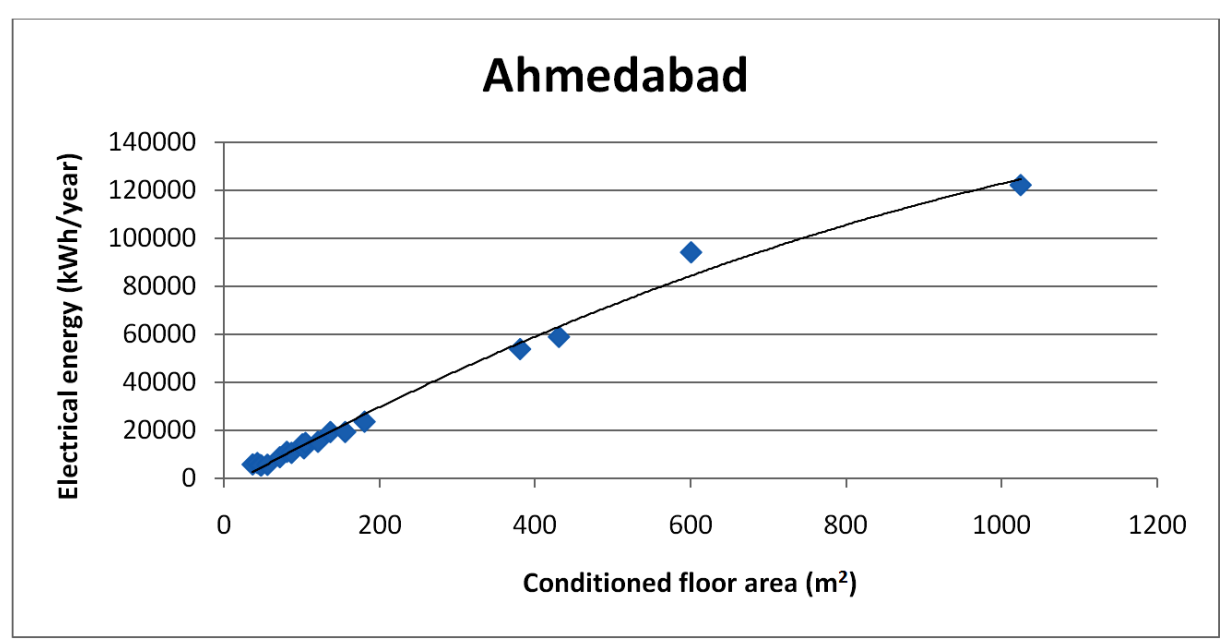

Figure 3. Variation of electrical energy demand of the buildings with conditioned floor area (Ahmedabad location).

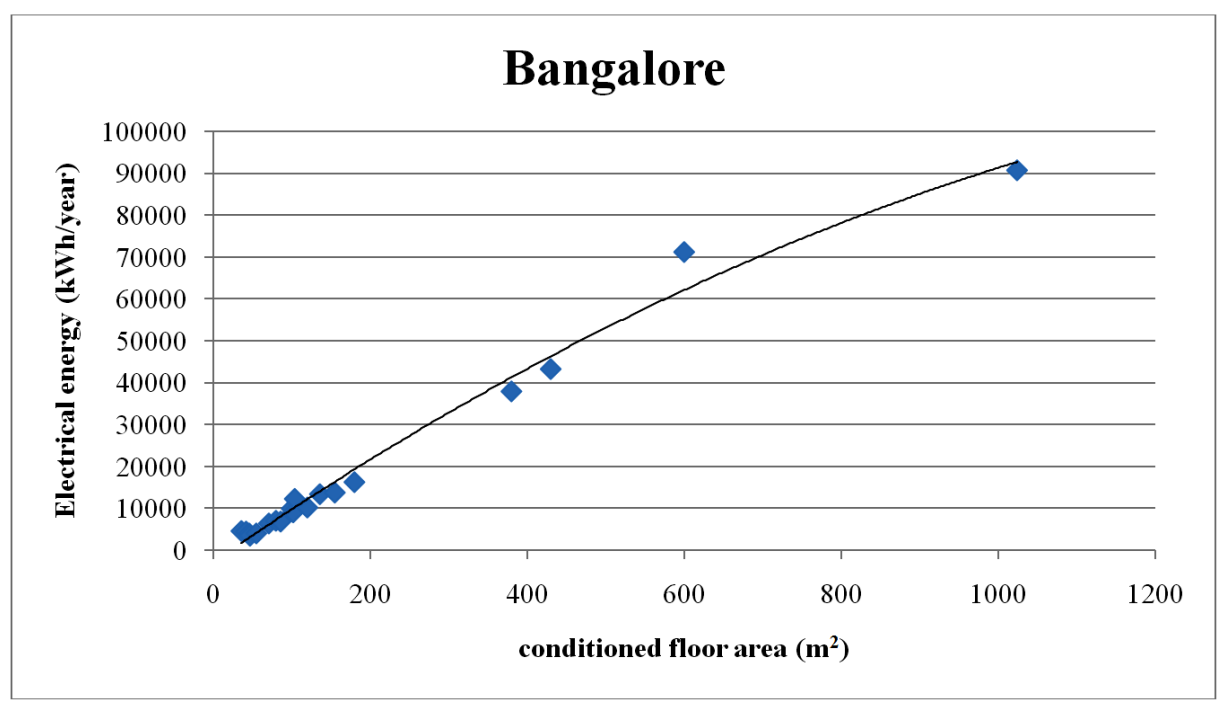

Figure 4. Variation of electrical energy demand of the buildings with conditioned floor area (Bangalore location).

Table 5. Regression coefficients for different locations.

\begin{tabular}{cccccc} 
& Hyderabad & Ahmedabad & Allahabad & Chennai & Bangalore \\
\hline A & -0.043 & -0.05 & -0.055 & -0.049 & -0.035 \\
B & 157.4 & 177.3 & 182.1 & 182.4 & 129.6 \\
C & -3388 & -3601 & -3951 & -3941 & -2925 \\
\hline
\end{tabular}

Thus, to estimate LCE of the conventional buildings (in $\mathrm{kWh} / \mathrm{m}^{2}$ year) following equations is proposed:

$$
\mathrm{LCE}=\mathrm{EBE}+E_{\mathrm{A}} / F A_{R}
$$

where

$\mathrm{EBE}=27.5$ for single storey houses; 22 for two and multi-storey houses,

$F A_{R}=$ Floor area (usable) of the building.

Tables 6-8 present LCE of the buildings with passive features (thermal insulation on envelope and double pane glass for windows) for different locations. LCE savings with passive features is about $5 \%$ - 30\% depending 
Table 6. LCE and savings \% (values shown in parenthesis) from energy saving measures (Ahmedabad location).

\begin{tabular}{|c|c|c|c|}
\hline BIN & Name & Case A & Case B \\
\hline 1 & Resha & 309 & $256(17.2)$ \\
\hline 2 & Harish & 273 & 232 (15) \\
\hline 3 & Janardhan & 218 & $174(20.2)$ \\
\hline 4 & Goud & 245 & 203 (17.1) \\
\hline 5 & Eashwer & 293 & $260(11.3)$ \\
\hline 6 & Srinivas & 298 & 243 (18.5) \\
\hline 7 & Ravindra & 305 & 254 (16.7) \\
\hline 8 & Adil & 330 & 274 (17) \\
\hline 9 & Keerthi & 376 & 265 (29.5) \\
\hline 10 & Abhishek & 279 & $256(8.2)$ \\
\hline 11 & Alwal & 297 & $240(19.2)$ \\
\hline 12 & Nirmal & 304 & $273(10.2)$ \\
\hline 13 & Mahipal & 318 & 282 (11.3) \\
\hline 14 & Anand & 285 & 257 (9.8) \\
\hline 15 & RG Reddy & 318 & $285(10.4)$ \\
\hline 16 & Mahendra & 334 & 312 (6.6) \\
\hline 17 & Kiran Arcade & 271 & $261(3.7)$ \\
\hline 18 & Renuka & 336 & $310(7.7)$ \\
\hline 19 & Pradeep & 258 & $237(8.1)$ \\
\hline 20 & Rock Town & 349 & $335(4)$ \\
\hline
\end{tabular}

Table 7. LCE and savings \% (values shown in parenthesis) from energy saving measures (Hyderabad location).

\begin{tabular}{|c|c|c|c|}
\hline BIN & Name & Case A & Case B \\
\hline 1 & Resha & 265 & 231 (12.8) \\
\hline 2 & Harish & 235 & 212 (9.8) \\
\hline 3 & Janardhan & 193 & $163(15.5)$ \\
\hline 4 & Goud & 203 & $173(14.8)$ \\
\hline 5 & Eashwer & 267 & 249 (6.7) \\
\hline 6 & Srinivas & 259 & $226(12.7)$ \\
\hline 7 & Ravindra & 269 & 237 (11.9) \\
\hline 8 & Adil & 294 & 253 (13.9) \\
\hline 9 & Keerthi & 327 & 242 (26) \\
\hline 10 & Abhishek & 246 & 237 (3.7) \\
\hline 11 & Alwal & 266 & $220(17.3)$ \\
\hline 12 & Nirmal & 271 & 254 (6.3) \\
\hline 13 & Mahipal & 278 & 257 (7.6) \\
\hline 14 & Anand & 255 & 238 (6.7) \\
\hline 15 & RG Reddy & 276 & $260(5.8)$ \\
\hline 16 & Mahendra & 301 & $289(4)$ \\
\hline 17 & Kiran Arcade & 247 & 244 (1.2) \\
\hline 18 & Renuka & 298 & 287 (3.7) \\
\hline 19 & Pradeep & 230 & 219 (4.8) \\
\hline 20 & Rock Town & 317 & 312 (1.6) \\
\hline
\end{tabular}

BIN: Building Identification Number. 
on the type, layout, and conditioned floor area of the buildings and also climatic conditions of locality. Single storey houses have better LCE savings than two and multi-storey houses because reduction in thermal load per unit floor area, due to thermal insulation on envelope, is higher for single storey houses than two and multi-storey houses.

Table 9 presents LCE savings of a single storey house with varying number of PV modules (on-site power generation) in combination with passive features. There is 30\% to $70 \%$ reduction in LCE of the building. Use of $\mathrm{PV}$ modules seems to be most promising for primary energy reduction of the buildings.

Table 8. LCE and savings from energy saving measures for other locations.

\begin{tabular}{|c|c|c|c|c|c|c|}
\hline \multirow{2}{*}{ Name of the building } & \multicolumn{2}{|c|}{ Allahabad } & \multicolumn{2}{|c|}{ Chennai } & \multicolumn{2}{|c|}{ Bangalore } \\
\hline & LCE & Savings \% & LCE & Savings \% & LCE & Savings $\%$ \\
\hline Resha & 251 & 17 & 259 & 17 & 209 & 8 \\
\hline Harish & 233 & 14 & 236 & 14 & 187 & 6 \\
\hline Janardhan & 175 & 20 & 169 & 19 & 152 & 8 \\
\hline Goud & 200 & 18 & 191 & 19 & 155 & 5 \\
\hline Eashwer & 259 & 10 & 260 & 13 & 233 & 6 \\
\hline Srinivas & 243 & 18 & 238 & 21 & 211 & 5 \\
\hline Ravindra & 256 & 17 & 264 & 15 & 218 & 5 \\
\hline Adil & 282 & 18 & 271 & 19 & 229 & 8 \\
\hline Keerthi & 263 & 29 & 251 & 30 & 206 & 19 \\
\hline Abhishek & 252 & 10 & 265 & 8 & 195 & 3 \\
\hline Alwal & 235 & 19 & 238 & 18 & 171 & 13 \\
\hline Nirmal & 275 & 13 & 282 & 6 & 216 & 6 \\
\hline Mahipal & 276 & 15 & 289 & 10 & 217 & 4 \\
\hline Anand & 259 & 10 & 267 & 9 & 200 & 3 \\
\hline RG Reddy & 283 & 7 & 293 & 7 & 216 & 2 \\
\hline Mahendra & 305 & 8 & 316 & 8 & 241 & 6 \\
\hline Kiran Arcade & 261 & 5 & 271 & 3 & 207 & 1 \\
\hline Renuka & 310 & 7 & 324 & 7 & 240 & 1 \\
\hline Pradeep & 237 & 9 & 245 & 7 & 188 & 2 \\
\hline Rock Town & 331 & 4 & 354 & 3 & 266 & 1 \\
\hline
\end{tabular}

Table 9. LCE and savings (values in bracket) for different cases of a house (Janardhan).

\begin{tabular}{|c|c|c|c|c|c|c|}
\hline \multirow{2}{*}{ Case } & \multicolumn{6}{|c|}{ Cities } \\
\hline & Ahmedabad & Allahabad & Chennai & Bangalore & Hyderabad & Remarks \\
\hline Case A & 218 & 219 & 209 & 165 & 193 & Conventional \\
\hline Case B & $174(16)$ & $175(17)$ & 169 (19) & $152(3)$ & $163(10)$ & Passive \\
\hline Case B + 20 PV modules & $128(38)$ & 131 (38) & $120(42)$ & 111 (29) & $117.4(35)$ & On-site (part load) \\
\hline Case B + 40 PV modules & $72.4(65)$ & $76.8(63)$ & 65 (69) & $62.4(60)$ & $62.5(65)$ & On-site (part load) \\
\hline Case B + Y No. PV modules & $\begin{array}{c}56.7(73), \\
Y=60\end{array}$ & $\begin{array}{c}56.7(73), \\
Y=60\end{array}$ & $\begin{array}{c}55(74) \\
Y=52\end{array}$ & $\begin{array}{l}55(65) \\
Y=52\end{array}$ & $\begin{array}{c}55(70) \\
Y=52\end{array}$ & $\begin{array}{l}\text { On-site (self } \\
\text { sufficient) }\end{array}$ \\
\hline
\end{tabular}




\section{Conclusions}

LCE of the buildings is varying from $160-380 \mathrm{kWh} / \mathrm{m}^{2}$ year depending on the type (geometry) of the building and climatic conditions. With insulation on wall and roof along with double pane glass for windows, reduction in LCE of the buildings is about 5\% - 30\%. LCE of the buildings can be further reduced by on-site power generation from PV system (30 to 70\%). A polynomial equation is proposed to readily reckon LCE of the new buildings. However, such equation needs to be improved when large number of LCE data is available in future.

The results of the present study are useful for building designers involved in design and construction of the energy efficient buildings and for policy makers to set meaningful targets. Some other cooling techniques like free cooling, evaporative cooling, solar air conditioning etc., may be tested to bring down LCE of the buildings. Use of energy efficient cooling/heating equipment and appliances would also reduce LCE of the buildings considerably.

\section{References}

[1] Bansal, N.K. (2007) Energy Security, Climate Change and Sustainable Development. In: Mathur, J., Wagner, H.J. and Bansal, N.K., Eds., Science, Technology and Society: Energy Security for India, Anamaya Publishers, New Delhi, 15-23.

[2] Ministry of Power, Government of India (2010) Performance Based Rating and Energy Performance Benchmarking for Commercial Buildings in India. http://www.powermin.nic.in/JSP_SERVLETS/internal.jsp

[3] Adalberth, K., Almgren, A. and Petersen, E.H. (2001) Life Cycle Assessment of Four Multi-Family Buildings. International Journal of Low Energy and Sustainable Buildings, 2, 1-21.

[4] Kofoworola, O.F. and Gheewala, S.H. (2008) Environmental Life Cycle Assessment of a Commercial Office Building in Thailand. International Journal of Life Cycle Assessment, 13, 498-511. http://dx.doi.org/10.1007/s11367-008-0012-1

[5] Junnila, S., Horvath, A. and Guggemos, A.A. (2006) Life-Cycle Assessment of Office Buildings in Europe and the United States. Journal of Infrastructure Systems, 12, 10-17. http://dx.doi.org/10.1061/(ASCE)1076-0342(2006)12:1(10)

[6] Adalberth, K. (1999) Energy Use in Four Multi-Family Houses during Their Life Cycle. International Journal of Low Energy and Sustainable Buildings, 1, 1-20.

[7] Winther, B.N. and Hestnes, A.G. (1999) Solar Versus Green: The Analysis of a Norwegian Row House. Solar Energy, 66, 387-393. http://dx.doi.org/10.1016/S0038-092X(99)00037-7

[8] Citherlet, S. and Defaux, T. (2007) Energy and Environmental Comparison of Three Variants of a Family House during Its Whole Life Span. Building and Environment, 42, 591-598. http://dx.doi.org/10.1016/j.buildenv.2005.09.025

[9] Yohanis, Y.G. and Norton, B. (2006) Including Embodied Energy Considerations at the Conceptual Stage of Building Design. Power and Energy, 220, 271-288. http://dx.doi.org/10.1243/095765006X76009

[10] Fay, R., Treloar, G. and Iyer-Raniga, U. (2000) Life-Cycle Energy Analysis of Buildings: A Case Study. Building Research \& Information, 28, 31-41. http://dx.doi.org/10.1080/096132100369073

[11] Utama, A. and Gheewala, S.H. (2008) Life Cycle Energy of Single Landed Houses in Indonesia. Energy and Buildings, 40, 1911-1916. http://dx.doi.org/10.1016/j.enbuild.2008.04.017

[12] Adalberth, K. (1997) Energy Use during the Life Cycle of Buildings: A Method. Building and Environment, 32, 317320. http://dx.doi.org/10.1016/s0360-1323(96)00068-6

[13] Adalberth, K. (1997) Energy Use during the Life Cycle of Single-Unit Dwellings: Examples. Building and Environment, 32, 321-329. http://dx.doi.org/10.1016/s0360-1323(96)00069-8

[14] Treloar, G., Fay, R., Love, P.E.D. and Iyer-Raniga, U. (2000) Analysing the Life-Cycle Energy of an Australian Residential Building and Its Householders. Building Research \& Information, 28, 184-195. http://dx.doi.org/10.1080/096132100368957

[15] QE-Pro (2010) Quantity Estimation \& Project Management Software. www.softtech-engr.com

[16] DA (Development Alternatives) (1995) Energy Directory of Building Materials. Building Materials \& Technology Promotion Council, New Delhi.

[17] Reddy, B.V.V. and Jagadish, K.S. (2003) Embodied Energy of Common and Alternative Building Materials and Technologies. Energy and Buildings, 35, 129-137. http://dx.doi.org/10.1016/s0378-7788(01)00141-4

[18] TERI (The Energy and Resources Institute) (2004) Sustainable Building Design Manual, Volume 2, Sustainable Building Design Practices. New Delhi, 91-112. 
[19] Gupta, T.N. (1998) Building Materials in India. Building Materials \& Technology Promotion Council, New Delhi.

[20] DesignBuilder-Building Design, Simulation and Visualization (2010) www.designbuilder.co.uk.

[21] TERI Press (2007) TEDDY TERI Energy Data Directory and Year Book 2005-06. New Delhi.

[22] E-Quest (2009) The Quick Energy Simulation Tool. http://www.doe2.com/equest

[23] Arvind, Ch., Tiwari, G.N. and Chandra, A. (2009) Simplified Method of Sizing and Life Cycle Cost Assessment of Building Integrated Photovoltaic System. Energy and Buildings, 41, 1172-1180.

http://dx.doi.org/10.1016/j.enbuild.2009.06.004 
Scientific Research Publishing (SCIRP) is one of the largest Open Access journal publishers. It is currently publishing more than 200 open access, online, peer-reviewed journals covering a wide range of academic disciplines. SCIRP serves the worldwide academic communities and contributes to the progress and application of science with its publication.

Other selected journals from SCIRP are listed as below. Submit your manuscript to us via either submit@scirp.org or Online Submission Portal.
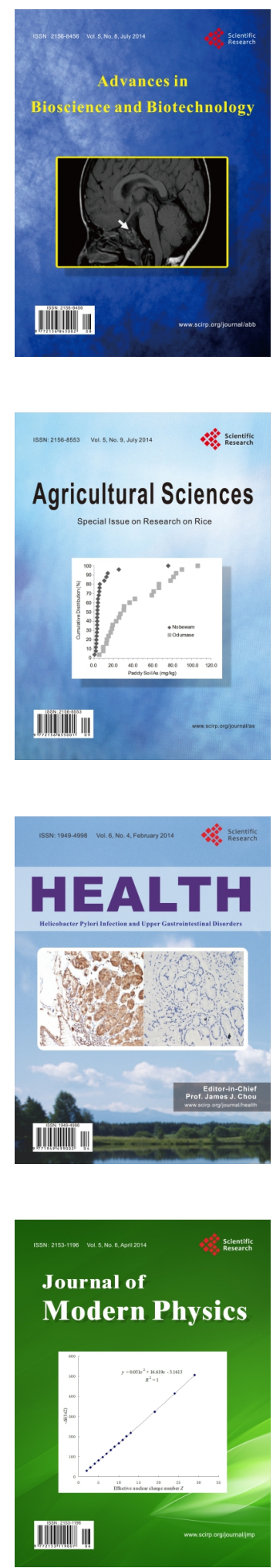
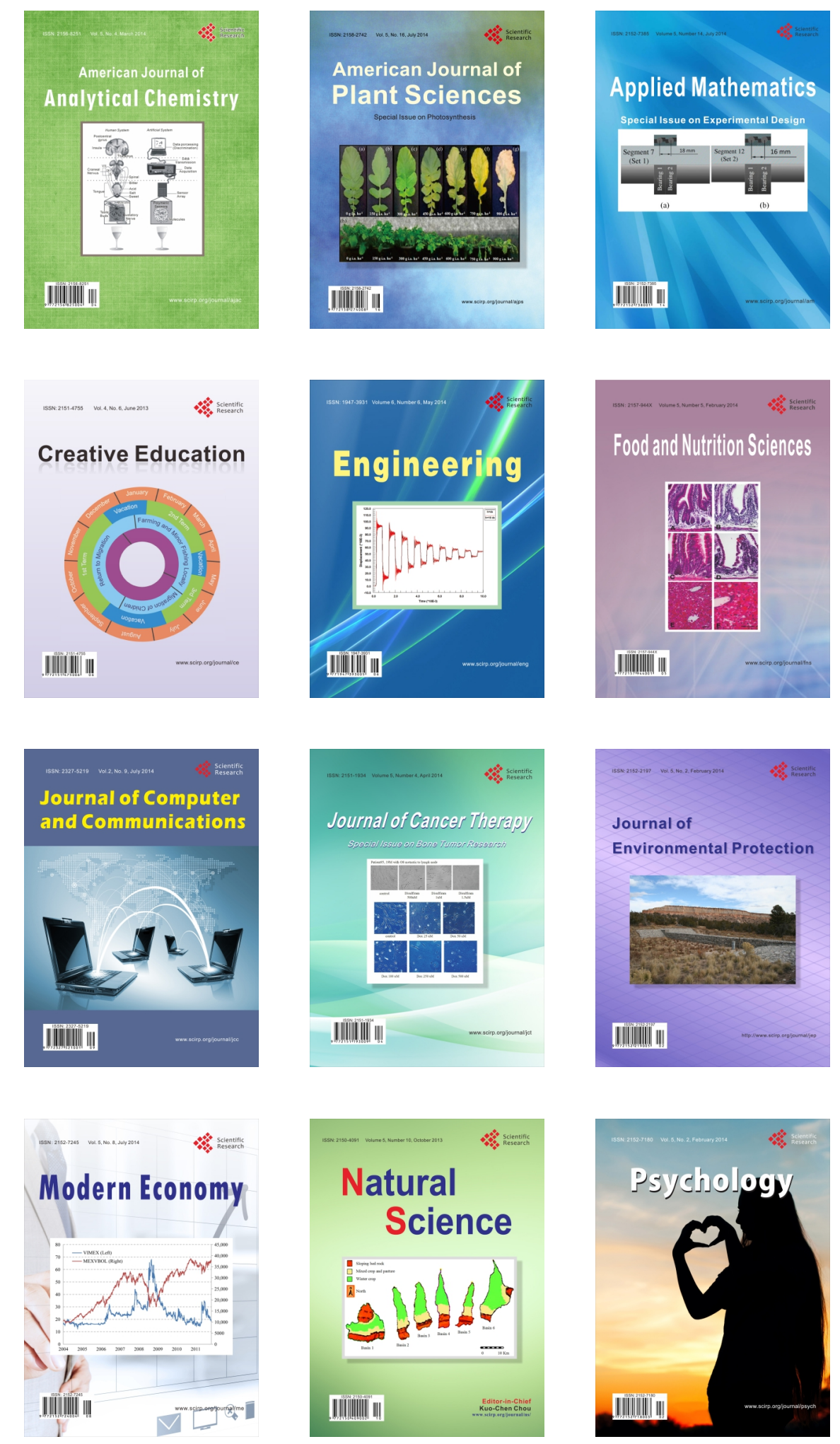